\title{
"Rubbing away their roughness by mutual contact": Post-Confederation Irish writers and Canadian National Identity
}

\section{Raymond Jess}

\section{(2) OpenEdition \\ 1 Journals}

\section{Electronic version}

URL: http://journals.openedition.org/etudesirlandaises/4862

DOI: 10.4000/etudesirlandaises.4862

ISSN: 2259-8863

\section{Publisher}

Presses universitaires de Rennes

\section{Printed version}

Date of publication: 15 June 2016

Number of pages: 155-166

ISBN: 978-2-7535-5091-9

ISSN: 0183-973X

\section{Electronic reference}

Raymond Jess, " "Rubbing away their roughness by mutual contact": Post-Confederation Irish writers and Canadian National Identity », Études irlandaises [Online], 41-1 | 2016, Online since 15 June 2018, connection on 19 April 2019. URL : http://journals.openedition.org/etudesirlandaises/4862 ; DOI : 10.4000/etudesirlandaises.4862 


\title{
"Rubbing away their roughness by mutual contact": Post-Confederation Irish Witers and Canadian National Identity
}

\author{
Raymond Jess \\ Concordia University, Montreal
}

Abstract

This article will look at how two Irish writers in nineteenth and early twentieth century Montreal used the print culture of their new Canadian home as a way of conceptualizing a burgeoning national community. Through various published articles in the Canadian periodical press, the Donegal-born poet John Reade tried to imagine a hybrid national identity molded from the many different cultures that inhabited the new Dominion. Reade's fellow Irish-born poet William Henry Drummond hoped that his own poetic sketches of rural Québec would help Anglo-Canadians better understand the cultural life of their French-Canadian compatriots.

Keywords: nationalism, narrative, anglophone, publishing, hybridity, John Reade, William Henry Drummond

\section{Résumé}

Cet article posera un regard sur la manière dont deux écrivains irlandais à Montréal, au XIX et au début du XX siècle, ont utilisé la culture imprimée de leur nouveau domicile canadien comme une façon de conceptualiser une communauté nationale en plein essor. Grâce à divers articles parus dans la presse périodique canadienne, le poète de Donegal John Reade a essayé d'imaginer une identité nationale hybride façonné par les différentes cultures qui ont habité le nouveau territoire. Son compatriote, le poète irlandais William Henry Drummond, espère que ses propres esquisses poétiques du Québec rural aideront les anglo-canadiens à mieux comprendre la vie culturelle de leurs compatriotes canadiens-français.

Mots clés : nationalisme, récit, anglophone, édition, hybridité, John Reade, William Henry Drummond

In 1858 Thomas D'Arcy McGee published a collection of verse called Canadian Ballads, eulogizing the actions of major figures in Canadian history. In his introduction to the collection he stated that of all forms of patriotism, a publicspirited patriotism in literature was not the least admirable ${ }^{1}$. Originally from

1. Thomas D'Arcy McGee, Canadian Ballads and Occasional Verses, Montreal, J. Lovell, 1858, p. 7. 
Carlingford, Co. Louth, McGee would go on to become one of Canada's founding fathers and was instrumental in guaranteeing minority education rights in the confederation of the Canadian provinces in 1867 . But it was as a member of the Young Irelanders in the 1840s that McGee first recognized the necessity of a national literature for establishing the narrative of nation. Like many other former Young Irelanders of his generation McGee brought with him to the new world a belief that the development of a distinctive cultural identity was intrinsic to the success of the modern nation-state. McGee's initial Canadian political project was an attempt to create a national literature that would both acknowledge and transcend this cultural diversity. It comes as no surprise that many of those Canadian writers who took up the mantle of McGee's project were themselves Irish-born, for where else in the United Kingdom at this time did cultural and religious differences cause such deep and unbridgeable divisions?

For the historian Adrian Hastings, the nation is a much more self-conscious community than any particular ethnicity as it can be formed from more than one ethnic identity and, more importantly it can generate its own national literature ${ }^{2}$. However, despite the fact that the nation can be formed from more than one ethnicity, more often than not the national literature is written in a single language. The literary historian Patrick Ward has highlighted how in writing in English the Young Ireland movement borrowed the codes, conventions and epistemologies of British and Anglo-Irish representations of the Gaelic Irish population ${ }^{3}$. In Canada the anglophone writers and nationalist intellectuals who followed the example of McGee were attempting to create a new national narrative that would supersede not only the enduring historical divisions that existed in Britain and Ireland, but also to incorporate the non-British and non-Irish ethnicities they shared the new dominion with. While these literary attempts may have been relatively successful at transcending differences between the English, the Irish and the Scottish, it will be important to examine whether McGee's disciples were as successful at transcending differences beyond Canada's anglophone identities.

McGee was an important intellectual link between Young Ireland and the Canadian poets of the post-Confederation era. Like the other Young Irelanders of his generation McGee felt that cultural nationalism's primary role was the moral rejuvenation of the community and the dissemination of historical memory ${ }^{4}$. Although he felt that Canada could learn from the examples of other nations, he also called for the rejection of what he saw as cheap imports of English and American literature because he felt that they dealt with subjects and themes that

\footnotetext{
2. Umut Özkirmli, Theories of Nationalism: A Critical Introduction, $2^{\text {nd }}$ ed. Houndmills, Basingstoke; New York, Palgrave Macmillan, 2010, p. 58.

3. Ward, Patrick. Exile, Emigration, and Irish Writing, Dublin/Portland, OR/Irish Academic Press, 2002, 92.

4. John Hutchinson, The Dynamics of Cultural Nationalism, London, Allen \& Unwin, 1987, p. 9.
} 
weren't directly related to the Canadian physical or material environment ${ }^{5}$. His advice to nascent Canadian writers was never more eloquently expressed than in the poem "Arm and Rise" in Canadian Ballads. Calling on Canadians to write Canada as they colonize and settle the land, he reminds them "On the round Canadian cedars/Legends high await but readers ${ }^{63}$.

Writing in the New Dominion Monthly in the years after his assassination ${ }^{7}$, McGee's friend and fellow Montreal Irishman John Reade acknowledged the literary power of the Young Irelanders, identifying how they used songs and popular ballads as "a leading medium for the dissemination of national feeling". Although John Reade was twelve years younger than McGee, his involvement in the Canadian literary scene preceded that of McGee by two years. Reade was born on $13^{\text {th }}$ November 1837 in Ballyshannon in Co. Donegal. Educated at Portora School, Enniskillen, and Queen's College, Belfast, he emigrated with his parents to Montreal in 1856. In the year of his arrival, at the age of just nineteen, he founded the Montreal Literary Magazine?. For the next sixty years, Reade would devote himself to the development of a national literature in Canada. As a trained (but ultimately unsuccessful) Anglican minister, Reade felt keenly that the prejudices and sectarianism of the old country should be left behind there. Like McGee, Reade's pre-Confederation writings envisioned a future Canada where a hybrid national identity would be formulated out of the many different cultures that inhabited the new dominion. In one such article from 1864 titled "Our Canadian Village", Reade walks his readers through his vision of an archetypal Canadian community. He leads his readers past numerous churches of all Christian denominations and introduces them to the village's inhabitants, who are a tried and tested mixture of national stereotypes; the argumentative Irishman, the thrifty Scot, the enterprising American and the affable French-Canadian.

While this early image of pre-Confederation Canada has a benign quaintness about it, Reade's first and only collection of poetry, The Prophecy of Merlin and Other poems, published in the aftermath of Confederation, provided a more violent image of national unity. The shedding of blood is a frequent theme in Reade's early poetry of national identity. In one of his best-known poems, "Has-

5. Thomas D'Arcy McGee, The Mental outfit of the New Dominion, Gazette, Montreal, and Montreal Literary Club, 1867 , p. 6.

6. Thomas D’Arcy McGee, "Arm and Rise", Canadian Ballads and Occasional Verses, Montreal, J. Lovell, 1858, p. 44.

7. McGee was assassinated on the doorstep of his Ottawa home on the 7 April, 1868. It was believed his assassination was planned and executed by the Fenians for what they felt was McGee's betrayal of his former republicanism. An Irish immigrant by the name of James Whelan was eventually tried, convicted and executed for his murder.

8. John Reade, “Thomas D'Arcy McGee - The Poet”, The New Dominion Monthly, [Feb, 1870], p. 17.

9. Leslie Monkman, "Reade, John”, Dictionary of Canadian Biography Online, Ottawa, National Archives of Canada and National Library of Canada, 2003, Accessed 29 June 2015. 
tings", he views the Norman invasion of England as a bloody and necessary prerequisite to the creation of a new race:

The Sussex woods were bright and red on that October morn; And Sussex soil was red with blood before the next was born; But from that red united clay another race did start On the great stage of destiny to act a noble part ${ }^{10}$.

Reade goes on to describe how the Battle of Hastings was the culmination of a long history of invasions and racial hybridity that would see the blood of the Celts, the Romans, the Saxons and the Vikings mingle with that of the Normans to produce the modern-day British people. Reade calls on his fellow Canadians to remember the Battle of Hastings as the moment when distinct peoples were brought together to create a new nation, "And as we gather into one let us recall with pride / That we are of the blood of those who fought where Harold died ${ }^{11}$ ". This idea of a shared Norman culture between British and French-Canadians was a prominent feature of late-nineteenth-century Canadian nationalism ${ }^{12}$.

In the newly confederated Canada Reade's conception of the Canadian village would have to be extended beyond Upper and Lower Canada (now called Ontario and Québec) to include the Maritime provinces of Nova Scotia and New Brunswick. In the aftermath of 1867 , numerous nationalist voices were calling for greater assimilation of Canada's different ethnicities. As D’Arcy McGee had said in the run up to Confederation "not French-Canadian, nor British-Canadian nor Irish-Canadian - patriotism rejects the prefix ${ }^{13}$ ". This was in line with prime minister John A. Macdonald's belief in a strong centralized government, one that would overcome the lingering legacy of pre-Confederation provincialism. However, within twenty years the political and economic ties that were holding Confederation together were on shaky ground. The execution of Louis Riel in 1885 had intensified already existing tensions between British and French Canadians. This, coupled with poor economic performance nationally, led some commentators to suggest that Canada would eventually be annexed by the United States ${ }^{14}$. The threat of annexation by the southern republic forced many cultural commentators into a defence of Canada's place as a politically distinct British ${ }^{15}$

10. "Hastings" in John Reade, The Prophecy of Merlin and Other Poems, Montreal, Dawson Bros., 1870, p. 100-101.

11. Ibid., p. 102.

12. Colin M. Coates and Cecilia Morgan, Heroines and History: Representations of Madeleine De Verchères and Laura Secord, Toronto; Buffalo, University of Toronto Press, 2002, p. 53.

13. Thomas D'Arcy McGee, "American Relations and Canadian Duties", Speeches and Addresses Chiefly on the Subject of British-American Union, London, Chapman and Hall, 1865, p. 37.

14. Carl Berger, The Sense of Power, Toronto, University of Toronto Press, 1970, p. 4.

15. "British" was largely used at this time as meaning a subject of the British Empire, rather than the narrower meaning of a resident of the island of Britain. British imperial sentiment was particularly strong among anglophone Canadians. Philip Buckner and R. Douglas Francis write: “...the descendants of Irish and Scottish 
nation on the North American continent, and also to a greater appreciation of the uniqueness of Canada's different ethnic cultures.

In his opening speech as first president for the Society of Canadian Literature formed in 1889 , Reade stated that now that the railroad had unified the country, Canadians could finally put provincialism aside and develop a greater knowledge and interest in the different cultures of all Canadians ${ }^{16}$. Since the publication of his poetry in 1870 , Reade had moved away from creative writing and had increasingly turned his attention to Canadian historical scholarship. He was passionate in his study of Native American language and literature, and believed that allowing Native languages to vanish without studying their history "would be a neglect only less blameworthy than the destruction of the historical monuments of Central America and Mexico ${ }^{17}$ ". He wished to preserve much of the heritage of aboriginal people as a way of laying the foundations for a national culture. Reade hoped to develop a sense of enlightened imperialism where intermixing between cultural groups would allow the nation to uncover its latent vitality. He painted a picture of a multi-national Canada, where, through a liberal education system, different nationalities would eventually meld into an idealized Canadian subject. He described this process as "rubbing away their roughness by mutual contact ${ }^{18 "}$. In his 1892 article on the study of folklore in Canada, Reade spoke of his desire to include all of Canada's peoples in the development of a unique communal identity:

[...] there is surely no reason why, in the Dominion of Canada, with our Esquimaux [sic] and Indians, our French and English, with their kinships and their diversities, our Celts of Wales and Man, of Ireland

\footnotetext{
immigrants to Canada have succeeded in disassociating themselves from their British imperial past and in presenting themselves as part of the colonized rather than as the colonizers, thus laying the blame for imperial exploitation on the English and their descendants. This is of course a serious distortion of reality. What existed in Canada was a shared British culture in which all of the various immigrant communities from the British Isles, included the Scots and the Irish contributed." Phillip Buckner and R. Douglas Francis, Canada and the British world, Vancouver, UBC Press, 2006, p. 6. Both John Reade and William Henry Drummond were raised in the Anglican Church of Ireland and would have had experienced little difficulty in reconciling their Irish and British identities. Indeed, Reade would go on to write a defence of British imperialism, admitting that while it was a flawed system, it was the best system that Canada could choose considering the alternatives. See "What is imperialism?" Canadian Magazine, 19 (May-October 1902): 316-18. On his first visit back to Ireland in 1902 after 38 years in Canada, Drummond was shocked at the visible rise of Catholicism outside of the northeast of Ireland. Fearing for the future of the Protestant community in his former home, he wrote to his wife "What an unhappy, wretched country is the West of Ireland... Home Rule be $\mathrm{d}-\mathrm{d}$ ! and to $\mathrm{h}$ - with the priests" - Personal letter from W.H. Drummond to his wife May Harvey Drummond (Manuscript Reference: 10.2/7), from the William Henry Drummond Family Fonds at The Osler Library of the History of Medicine, McGill University, Montreal, Canada.

16. "Canadian Literature", The Gazette, Montreal, 29 January, 1889, p. 2.

17. John Reade, The Literary Faculty of the Native Races of America, Montreal, Dawson, 1884, p. 30.

18. John Reade, "Our Canadian Village”, British American Magazine, 2(5), 1864, p. 483.
} 
and the Highlands, and our scattered colonies of Teutons, Norsemen, Hungarians and Chinese, all living amongst us the lives that their fathers led, professing their ancestral creeds and speaking their mother tongues, we, too, may not add our mite to the treasury of knowledge and make Canadian folk-lore a felt reality in the world ${ }^{19}$.

In a later article, Reade sought to remind his readership that the English were an amalgamation of Angles, Saxons, Jutes, Danes and Romans and that this mixture produced a great civilization, one which Canada would one day hope to supersede $e^{20}$. There is a yearning in these articles for cultural hybridity, an amalgamation of the most positive aspects of each ethnic identity. Reade placed special importance on seeing a place for Native peoples in this hybridization of Canadian identities. In an 1887 copy of the national periodical The Week, Reade pointed to a number of studies done by various anthropologists which showed that many of the Iroquois of Québec had intermarried with white families, allowing certain members of the Senate, the universities, the army and the navy to show what he called "visible native ancestry". It was believed that this blending of races would help to establish good will and peace between whites and natives. "Let us hope so", comments Reade, "so far unhappily it has not had that result either in the United States or Canada. But then look at the Celt and Saxon in Ireland after seven centuries of intercourse ${ }^{21}$ ". This reference to Ireland as an example of the difficulty of uniting two different ethnicities is Reade's warning against the political and cultural separation of different ethnic groups. Intermarriage between various ethnic groups such as the English, the Scottish, the Irish and the French should become a model for other new immigrant groups to adapt to an inter-ethnic rather than multi-ethnic Canada.

Such was Reade's enthusiasm for the unearthing of Canadian folklore he was eventually appointed vice-president of the Montreal chapter of the American Folklore Society, a position he shared with the Francophone poet and politician Louis Fréchette ${ }^{22}$. Fréchette had caused much excitement in Canadian literary circles when the Académie Française awarded him a Montyon prize in 1880 for his collection of poetry Les Fleurs boréales, les oiseaux de neige. This was the first time a Canadian writer had been acknowledged in such a way by a European nation $^{23}$. For anglophone Canadian cultural nationalists, such an award honou-

19. John Reade, "The Study of Folklore in Canada", The Dominion Illustrated Monthly, 1(5), 1892, p. 302.

20. John Reade, "Nation Building", The Week, 4(30), 1887, p. 480.

21. Ibid., p. 37.

22. "American Folklore Society, Montreal Branch" letterhead, 17 June 1895, in John Reade fonds (P 140), McCord Museum Archives, Montreal, Canada.

23. Jacques Blais, "Fréchette, Louis", Dictionary of Canadian Biography Online, Ottawa, National Archives of Canada and National Library of Canada, 2003, Accessed 29 December 2015. 
red not only Fréchette, but also the genius and distinctiveness of literature produced in Canada. Reade felt that such genius and distinctiveness could be better developed by greater dialogue between the English-speaking and French-speaking peoples of Canada. In his opening speech to the Society of Canadian Literature he remarked of Canada's two linguistic communities "As to society and literature, we are greater strangers than are the French and English of Europe...I have no hesitation in saying that the fault for the share which ignorance of each other's language has in keeping us in a state of alienation from each other lies at the door of the English rather than at the door of the French-Canadian $s^{24}$ ".

Such sentiments were echoed by Reade's Irish-Canadian contemporary, William Henry Drummond at a speech to the National Club in Toronto, "...as a member of the English speaking outpost of the old Province of Quebec I feel constrained to say that I believe it to be the patriotic duty of every intelligent British Canadian not to stand aloof from our French-speaking fellow countrymen, but to learn something of the language of France, to study the customs and the characteristics of the people, who are born with that language almost formed on their lips $s^{25}$. If it was the hope of Reade's generation of cultural nationalists that a distinctive Canadian literature could be born out of the marriage between the nation's two linguistic traditions, then no other writer of the era seemed to fulfil that hope more successfully than William Henry Drummond.

Drummond was born in Mohill, Co. Leitrim in 1854. His father was a policeman in the Irish Constabulary who was eventually dismissed from his position over an argument with a local landlord. Drummond emigrated with the rest of his family to Montreal in 1864 . He eventually trained as a medical doctor and went to work in the Eastern Townships of Québec. He began writing poetry about the French-Canadian habitant in the early 1870 s but his first volume of poetry The Habitant and other French-Canadian Poems wasn't published until $1897^{26}$. Much of Drummond's regular English language poetry was deemed quite stiff and overly-formal ${ }^{27}$. However, his verse writing in the broken English of the FrenchCanadian habitant was considered much more vigorous and animated. Drummond's poems of French-Canada were considered a sort of dialect poetry where he would try to imitate the speech of a people speaking English as a second language. His poetry readings were particularly popular at the time amongst a largely

24. “Canadian Literature”, The Gazette, Montreal, 29 January, 1889, p. 2.

25. William Henry Drummond, "Address to the National Club, Toronto, on Canadian Literature", unknown date, (Manuscript Reference: 30.6), from the William Henry Drummond Family Fonds at The Osler Library of the History of Medicine, McGill University, Montreal, Canada.

26. Mary Jane Edwards, "Drummond, William Henry", Dictionary of Canadian Biography Online, Ottawa, National Archives of Canada and National Library of Canada, 2003, Accessed 29 June 2015.

27. "In one or two instances, Dr. Drummond has forsaken dialect and the results are not happy", "The Voyageur", East Anglian Times, London, 28 August, 1905. 
English-speaking Canadian audience. The popularity of his poetry was largely due to the fact that it focused more on country people and their trials and tribulations than it did on the beauty of the natural landscape. Unlike the stifled formal language of the educated urban bourgeoisie, Drummond communicates the unassuming, frank opinions of his habitant characters in order to show his anglophone Canadian audience how the habitant enjoys life without the pretensions of material desire or social aspiration.

In the poem "The Curé of Calumette", Drummond emphasizes how the Irish and French-Canadians would make a good match for each other, echoing Reade's enthusiasm for cultural hybridity:

Hees fader is full-blooded Irish, an' hees moder is pure Canayenne, Not offen dat stock go tegedder, but she's fine combination ma frien' For de Irish he's full of de devil, an' de French dey got savoir faire, Dat's mak'it de very good balance an' tak' you mos' ev'ry w' $\operatorname{ere}^{28}$.

Much like his contemporaries in the Irish Literary Revival, Drummond looked to the rural hinterland as a natural repository of feeling and sentiment, and as a bulwark against the urban decadence of the modern city. In the late nineteenth century many French-Canadians left Canada looking for work in the larger towns and cities of urban New England. Drummond saw this as a troubling development, as Canada would be losing much of what made its culture distinctive. In the poem "How Bateese Came Home", Bateese is chided by his friend Napoleon for emigrating to the United States and returning home speaking English. He also remarks on how Bateese seems corrupted by the values of his new country and how his culture and family environment would be better protected if he stayed in Canada:

I say "For w' at you spik lak dat? you must be gone crazee Dere 's plaintee feller on de State, more smarter dan you be, Beside she 's not so healtee place, an' if you mak' l'argent, You spen' it jus' lak Yankee man, an' not lak habitant ${ }^{29}$.

Although the introduction to the original publication of The Habitant and Other French Canadian Poems was written in French by Louis Fréchette, francophone interpretations of Reade and Drummond's work were few and far between. However, when their work was reviewed in the francophone press, reviewers were likely to focus on their Irish origins. An insightful review of John Reade's poetry

28. "The Curé of Calumette" in William Henry Drummond, Complete Poems, Toronto, McClelland \& Stewart, 1926, p. 132.

29. "How Bateese Came Home”, in William Henry Drummond, Complete Poems, op. cit., p. 23. 
by the Francophone periodical Revue de Montréal in $1879^{30}$ points to a perceived link between Irish romantic sentiment and Catholic mysticism:

Mais M. John Reade, comme ce pauvre Darcy [sic] McGee, est bien et dûment un poète irlandais. La verte Erin a imprimé son cachet sur toutes ses cuvres, et, bien quil appartienne à l'église anglicane, où il a même étudié la théologie, ce cachet, sil veut bien nous permettre de le dire, est plutôt catholique que protestant. C'est le cas, du reste, pour la plupart des poètes et des orateurs protestants du pays de sa naissance ${ }^{31}$.

The idea that every Irish writer has a Catholic disposition no matter what their religion is an illuminating observation. Throughout much of the nineteenth century Anglo-Irish Protestant writers would develop an increasingly Romantic literary vision as their political power on the island began to diminish. This would ultimately culminate in the largely Protestant-led Irish Literary Revival of the late nineteenth and early twentieth centuries. There were many reasons for this turn towards the Romantic, one of which was to provide an outlet for the spiritual imagination that the Protestant faith couldn't accommodate in a post-Darwinian world. Protestantism had developed a strong disapproval of the mystical and tended to emphasize the mind over the heart and the literal over the emotional. These Protestant writers also hoped that celebration of a common Irish folklore would help to undermine religious differences in Ireland. In his pre-Confederation article "Our Canadian Village", Reade pointed to the lack of sectarianism in his idealized picture of a new Canada: "Christianity with its windings is also moving on to another sea - infinitely deep and broad. I only mean Christianity that is of Christ ${ }^{32}$."

But it wasn't just religious differences that had to be superseded, political differences also needed to be overcome. A Canadian identity had to be broad enough to embrace not only different kinds of ethnicity, but even ethnicities that may have had a history of enmity towards one another. The emigrant voyage from Ireland should also be a voyage away from Ireland's historic relationship with England. In Canada where Saxon and Celt needed to live and work alongside one another, old animosities would have to be abandoned without too much reflection. In his article on early Irish-Canadian Romanticism, Jason King has underscored how the immensity of the Canadian landscape led many Irish-Canadians to reassess Ireland's adversarial politics. The vastness of Canadian geography dwarfed Irish political histories. The environmental determinism of such a vast

30. For a francophone review of Drummond's work, see Pierre Lorraine, "Le Poète De L'Habitant", Le Journal de Françoise, 6(21), 2 février, 1908, p. 332.

31. H.V., "Un Poète Anglo-Canadien", Revue De Montréal, 3(3), 1879, p. 190.

32. John Reade, “Our Canadian Village”, British American Magazine, 2(5), 1864, p. 483. 
space would mean that people would need to work together to master its unforgiving terrain ${ }^{33}$.

While the grand sweep of the Canadian landscape was a powerful source of inspiration for Canadian Romanticism, the lack of a distinctive linguistic identity left Canadian intellectuals hungry for such poetic inventions as Drummond's habitant dialect. For nineteenth century German Romantic thinkers such as Johan Gottfried Herder, a particular language embodied the living heritage of a particular people, and poetry was the most democratic form of orally communicating the feelings and emotions of previous generations. Such ideas had special import in Ireland in the early nineteenth century as antiquarians sought to revive an oral Gaelic culture they perceived as being in permanent decline. The Young Irelanders also played a part in this linguistic nationalism by highlighting the uniqueness of Hiberno-English forms in their work. As Charles Gavan Duffy stated in his introduction to The Ballad Poetry of Ireland: 'There is an Anglo-Irish language as easily discriminated from London English as the dialect of Saxon spoken in the Lowlands of Scotland...It is a dialect fired with the restless imagination, and coloured with the strong passions of our nation ${ }^{34}$.

Drummond's poetry proved to be highly popular amongst Canadian critics and readership alike because they felt that here was something uniquely Canadian that no other culture could have created. Before Drummond, those who attempted to encourage the production and reading of Canadian literature appealed to a small number of Canadian nationalists. The reading material desired and chosen by most Canadians was still imported British and American literature ${ }^{35}$. Within a few years of its initial publication The Habitant and other French-Canadian Poems had sold 30,000 copies. By the time of Drummond's death in 1907 sales of Drummond's various poetry collections had reached over 60,000 copies $^{36}$. The irony of the success of The Habitant and other French-Canadian Poems was that while it dealt with specifically Canadian subjects, it was published by a New York publisher and proved just as popular in the northeastern U.S. and in the American states around the Great Lakes, as it did in Canada. Canadian writers shared a similar problem with their Irish counterparts in that if they wanted a large readership they had to look to the more populous anglophone audience of their nextdoor neighbour.

33. Jason King, "Prefiguring the Peaceable Kingdom: The Construction of Counter-Revolutionary Sentiment in Irish-Canadian Romantic Verse and Prose”, The Canadian Journal of Irish Studies, 31(1), 2005, p. 38-44.

34. Charles Gavan Duffy, The Ballad Poetry of Ireland, Dublin, J. Duffy, 1857, p. xxII.

35. D.M.R. Bentley, "Post-Confederation Poetry", in Coral Ann Howells and Eva-Marie Kröller (eds.), The Cambridge History of Canadian Literature, Cambridge, England, Cambridge University Press, 2009, p. 190.

36. Pierre Lorraine, “Le Poète De L'Habitant”, Le Journal de Françoise, 6(15), 2 Novembre, 1907, p. 236. 
Although Drummond's poetry proved to be extremely popular, there seemed to have been resistance from some quarters at the time regarding the depictions of French-Canadians in his poems. In her introduction to the posthumous 1908 collection of her husband's poetry, May Harvey Drummond pointed out that Louis Fréchette had defended her husband's poetry in the face of complaints put forward "by a few of the French-Canadian people of Québec, namely, that these verses were written in a spirit of mockery ${ }^{37 "}$. Unfortunately for Drummond's legacy, these accusations of mockery would only increase in the decades to come. The rising tide of Québécois nationalism in the 1960s and '70s meant that Drummond's habitant poems were increasingly seen as derogatory or even outright racist. By the 1980s Drummond seemed to have been quietly dropped from the Canadian literary canon. A standard poetry anthology used on Canadian literature courses today, Canadian Poetry from the Beginnings to the First World War, doesn't feature any of Drummond's poetry, despite the fact that he was the best-selling and most widely read Canadian poet of the immediate pre-First World War era ${ }^{38}$.

Even if Drummond's intention wasn't one of mockery, he still paints his habitant types as little more than pawns in the development of the Canadian nation. Rural Québec is for Drummond a place that never changes, where there is no advancement; time has come to a standstill. An illuminating story about Drummond's return to Ireland gives some indication of this psychological desire for a timeless rural haven. On a speaking trip to Britain in 1902, he had a strong desire to revisit the scenes of his childhood in Leitrim and Donegal. When he did return to Ireland, however, he only ended up staying a night in Dublin. The following morning he got back on the boat to Glasgow and returned home to Canada, never to visit Ireland again. In that one night in the Irish capital, Drummond realized that the Ireland of his childhood imagination could never be recaptured ${ }^{39}$. Instead he replaced it with the habitant world of French Canada, a place he could go back to again and again, secure in the knowledge that it had never changed. In some ways Drummond was compensating for the experience of exile and the dislocation of immigration by constructing an idyllic vision of rural Québec and French-Canadians that would emotionally replicate the lost world of childhood and home. Like other Canadian poets of the Confederation era, Drummond also looked to a world of cyclical time outside the ongoing advance of the industrial

37. William Henry Drummond \& May Harvey Drummond, The Great Fight; Poems and Sketches (Memorial ed.), New York, G.P. Putnam's Sons, 1908, p. 31.

38. See Carole Gerson and Gwendolyn Davies (eds) Canadian poetry: from the beginnings through the First World War, Toronto, McClelland \& Stewart, 1994.

39. Personal letter from W.H. Drummond to his wife May Harvey Drummond (Manuscript Reference: 10.2/7), from the William Henry Drummond Family Fonds at The Osler Library of the History of Medicine, McGill University, Montreal, Canada. 
world. He portrays the French-Canadian subjects of his poems as innocent children of nature, contrasting their vitality with their quaintness, oblivious to the forces of modernity. The habitant would safeguard Canada's rural idyll and not interfere with British Canadians' industrial progress. Canadians could then have the best of both worlds, appreciating the simplicity of the French-Canadian past alongside the prosperity of the British-Canadian future. If to share a language is to share a form of life, then ultimately Drummond's poetry was shared with a specifically anglophone audience across North America and beyond ${ }^{40}$. Similarly, John Reade's appreciation of Native literature and his wish for cultural hybridity disguised a more troubling desire for assimilation and appropriation. Reade's hybrid Canadian wasn't a unitary figure, someone who bridged identities and brought mutual understanding between natives and settlers; rather, intermarriage between natives and whites was seen as a way of "civilizing" native peoples and integrating them into the dominant European culture. This new Canadian was a culturally British subject who could now rightfully claim some ancient connection to the Canadian landscape.

While both Reade and Drummond answered McGee's call to find something unique about the Canadian experience that could be used to foster a new and novel national culture, ultimately their attempts were more about using the nonBritish subjects of their work as badges of difference from other anglophone cultures, (i.e. the United States and the rest of the Empire). It's difficult not to see in these discursive constructions of identity a longing by these writers to overcome the political fear and loathing that so marked their homeland. But although their intentions were to prevent any sectarian or bigoted dogmas from taking hold in the new peaceable kingdom of Canada, their discursive power would simply render other ethnic groups as passive and pliant to their own national imaginings.

40. In his novel Le Ciel de Québec, published in 1969, the Québécois author Jacques Ferron would even go so far as to joke that Drummond's French-Canadian patois was an entirely Irish invention: "De ce bel homme chaleureux Orphée acceptait tout. Il est irlandais, écossais, canayen. Il parle joual, vu que c’est une invention irlandaise, l'invention du Docteur Drummond qui, pareil au dénommé James Joyce, voulait rendre l'anglais incomprehensible." Jacques Ferron, Le ciel de Québec, Montréal, Éditions du Jour, 1969, p. 197. 